\title{
Types of Yes - No Questions Found in the Movie 500 Days of Summer
}

\author{
Apri Dita Rusanti \\ English Department - Faculty of Arts - Udayana University \\ [apridita22@gmail.com]
}

\begin{abstract}
The paper entitled "Types of Yes-No Question Found in the movie "500 Days of Summer" focuses on types of the English interrogative sentences especially yes-no question forms and their functions used in the movie 500 Days of Summer in 2009. The data were analyzed qualitatively in accordance with some relative theories. The theories used for this study are the theories of English yes-no questions taken from "Comprehensive Grammar of the English Language" by Quirk (1985) and "A Practical English Grammar" by Thomson A.J and A.V Martinet (1986). Then the data were presented descriptively by explaning the process and the result of discussion.Based on the findings there are five forms of English yes-no questions found in the data belonging to the Major classes of questions. Those English yes-no questions found in the data were possitive yes-no questions, negative yes-no questions, declarative questions, tag questions, yes-no questions with modal auxiliaries. The data were analyzed and some functions of the interrogative sentence were found: (a) Asking for request;(b) Confirmation; (c) Offering; (d) Asking for information; (f) Asking for permission .Mostly yes-no questions found in the data are asking for information and confirmation. However, suggestion and greeting do not exist in the data.
\end{abstract}

Keywords: interrogative sentences, yes-no question, function.

\begin{abstract}
Abstrak
Judulpenelitianiniadalah"Types of Yes-No Question Found in "500 Days of Summer Movie, fokus kepada jenis kalimat tanya dalam bahasa inggris terutama bentuk dan fungsi pertanyaan ya - tidak didalam film 500 Days of Summer tahun 2009. Data dianalisis secara qualitatif sesuai dengan beberapa teori yang berhubungan. Teoriteori yang digunakan dalam makalah ini adalah teori pertanyaan ya - tidak dalam bahasa inggris di buku "Comprehensive Grammar of the English Language" dari Quirk (1985) dan "A Practical English Grammar" dari Thomson A.J and A.V Martinet (1986). Lalu data yang sudah terkumpul dipresentasikan secara descriptif dengan menjabarkan proses dan hasil dari diskusi. Berdasarkan temuan ada lima bentuk pertanyaan ya - tidak dalam bahasa inggris yang ditemukan dari data adalah pertanyaan kategori umum. Pertanyaan ya - tidak yang ditemukan adalah pertanyaan ya - tidak positif, ya - tidak negatif, pertanyaan deklaratif, pertanyaan tag, pertanyaan ya - tidak dengan kata bantu. Ditemukan beberapa fungsi dari data yang telah dianalisis: (a) Menanyakan permintaan; (b) Konfirmasi; (c) Menawarkan; (d) Menanyakan informasi; (f) Meminta ijin. Pertanyaan ya - tidak yang ditemukan biasanya menanyakan informasi dan konfirmasi. Tetapi ,fungsi saran dan salam tidak ada ada didalam data.
\end{abstract}


Kata kunci: kalimat tanya, pertanyaan ya-tidak, fungsi.

\section{Background of the Study}

A sentence is a grammatical structure composed of one or more clauses and minimally combined a subject and a verb, but it may also contain object compliment and adverbial, conventionally written with an initial capital letter and final full stop or other terminators (Jackson 2002:98). One of the components of language is sentence. According to its function, sentences are divided into four such as interrogative, imperative, declarative, exclamatory sentence.

One of the parts in sentence is interrogative sentence. An interrogative sentence asks a question and therefore ends with a question mark. There are two main subclasses of interrogative clause. i.e. the open interrogativesand closed interrogatives,(Huddleston, 1991:134). A yes-no question is a question that asks to identify whether $\mathrm{P}$ or not $\mathrm{P}$ is true (Hamblin 1973), and is minimally answered by an answering particle.

Miles in Axelson (2006:3) emphasizes that the need to study contemporary popular film as a transmitter of attitudes and values of modern society. As a cultural critic she also understands film audiences as active interpreters of a film rather than as passive, helpless recipients of the information and values communicated through media.

\section{Problems of the Study}

a. What types of English yes-no question sentences are found in the movie 500 Days of Summer?

b. What is the function of yes-no question type found in the movie 500 Days of Summer?

\section{Aims of the Study}

a. To identify and describe yes-no question sentence type in the movie 500 Day of Summer.

b. To identify and describe the function of yes-no question sentence type in the movie 500 Days of Summer.

\section{Research Method}

The research method in this study consists of data source, method and technique of collecting data, and method and technique of analysing data.

\subsection{Data Source}

This study used the movie500 Days of Summer" as the data source. Then the data taken from the sentences used in the dialogue in the movie 500 Days of Summer and also the original script of the movie which has been published. This movie was chosen as the data source because there are a lot of sample of the type yes -no question used in the script and it tells us that love cannot control us, it will find us on a right time. 500 Days of Summerwas written by Scott Neustadter and Michael H. Weber, directed by Marc Webb. The data in this paper were taken from the movie entitled "500 Days of Summer' (2009). The movie is presented in a nonlinear narrative, jumping between various days within the 500 days of Tom and Summer's relationship. This is a linear summary of the plot. This movie tells about Tom Hansen, a man who works at a greeting card company but trained as an architect. In this office the story begins, when Tom's boss introduced Summer Finn as his new secretary. After that time, Tom is obsessed with Summer. Summer believes that women could enjoy and being free without being in a relationship, for her love is just a fantasy. But that what makes Tom fall in love with her. 


\subsection{Method and Technique of Collecting Data}

The method used in collecting the data is the documentation method. The process included first watching the movie and listening to the conversation of the characters in the movie, second reading the script of the movie in the script in order to find out yes-no question and find out the function and meaning of interrogative sentence type that found in the movie, third note taking the data and ordering them into a list.

\subsection{Method and Technique of Analyzing Data}

The study used descriptive-qualitative method in analyzing the data. The data were classified into 5 yes-no question types used the theory from Quirk et al (1985).The chosen data described in terms of the function based on the theory proposed by Thomson and Martinet (1986). The collected data were analyzed qualitatively in a descriptive way. The forms and their functions of the yes - no questions were analyzed by the theory mentioned above.

\section{Analysis}

\subsection{Yes - No Question and Its Function Found in the data}

This part consists of the analysis of yes no question form and function in the 500 Days of Summer Movie.

\subsubsection{Yes - No Questions}

There were five colours appearing in "Pond's Age Miracle" advertisement. There were white, pink, red, black and grey.

a. Interrogative sentence functionsas stating information
The function of the sentence as stating information whether Clarck flirting Tom or not.

Clarck:"(reading) Uh, "Roses are red, violets are blue."

"Fuck you, whore."

"Now, most shoppers at

Valentine's Day-“

Tom :"Mr. Vance, are you flirting me?"

Clark :"No. No." $\quad$ (00:55:43,506)

The form of the sentence "are you flirting me? "'belongs to yes-no question starting with the auxiliary are. The conversations occurred between two speakers; they were the first speaker (Clark) and the second speaker (Tom). This sentence needs a response. The response of the first speaker (Clark) is"No. No."

b. Interrogative sentence functions as asking for confirmation

Tom :"Shh. Everyone's looking over here."

Summer:"I'm done. I'm done."

Tom :"Are you done?"

Summer:"I'm done."

$(00: 52: 02,995)$

The example typed in italics above is yes - no question. It starts with the auxiliary are. The conversation involved 2 people as participants. Seen from the form of the sentence that it's asking the information that the first speaker asks the second speaker about whether she is done. However, if we look up at the function of the sentence, the sentence above is asking for the confirmation. We can say it because the second speaker said "I'm done. I'm done.". So the first speaker confirms it again. 
b. Interrogative sentence functioning to ask for permission

Tom :"That would explain a lot actually."

Alison :"Can I ask you a question?"

Tom :"Yeah."

Alison :"She never cheated on you?"

(00:59:38,408)

Seen from its form, the question form above in the sentence "Can I ask you a question?" belongs to yes-no question starting with the modal auxiliary can. The conversation occurred between the first speaker (Tom) and the second speaker (Alison). The interrogative sentence above functions to ask for permission. It shows that the second speaker (Alison) asks the permission to the second speaker (Tom) to ask him something.

c. Interrogative sentence functioning to state request

Tom :"Can you just be serious, for just a second?"

Summer:"I am being totally serious."

Tom :"No, you're joking around."

Summer:"No, I am not joking around." Octopus's Garden?"

(00:34:42,664)

Seen from its form, the example above"Can you just be serious, for just a second?" belongs to yes-no question starting with the modal auxiliary can. There are two participants involved in this conversation, the first speaker (Tom) and the second speaker (Summer). The conversation talks about Octopus's Garden. Seen from the function of the example sentence"Can you just be serious, for just a second?" functions to ask someone for something. d. Interrogative sentence functioning to ask for confirmartion (tag question)

Tom :"So why'd you dance with me?"

Summer :"Cause I wanted to."

Tom : :You just do what you want, don't you?"

"You never wanted to be anybody's girlfriend, and now you're somebody's wife."

Summer :"Surprised me too." (01:23:26,418)

Seen from the above example, the tag is negative with the positive statement. When the tag of a tag question is negative, it means the speaker hopes that it will be positive response. The form above has the function to ask the confirmation from the first speaker (Tom) to second speaker (Summer). We can see it from what the second speaker (Summer) saysthat"Cause I wanted to." Then, the first speaker (Tom) confirms again that she only does anything that she loved, followed with the statement "You never wanted to be anybody's girlfriend, and now you're somebody's wife." The response from the second speaker (Summer) is"Surprised me too."

e. Declarative interrogativequestionsfunctioning as offeringsomething

\begin{tabular}{|c|c|}
\hline Summer & $\begin{array}{l}\text { :'Please. I don't know } \\
\text { anything about } \\
\text { architecture." }\end{array}$ \\
\hline Tom & $\begin{array}{l}\text { :"You want me to draw } \\
\text { you something?" }\end{array}$ \\
\hline Summer & :"Yeah." \\
\hline Tom & :"I don't have any paper." \\
\hline $\begin{array}{l}\text { Summer } \\
(00: 3\end{array}$ & $\begin{array}{l}: ’ W e l l, \text { use my arm.” } \\
28,83)\end{array}$ \\
\hline
\end{tabular}

The above form typed in italics belongs to the yes-no declarative 
question. The declarative interrogative can be changed with a true interrogative sentence Do you want me to draw you something? So it can be a positive yes-no question. Here two participants are involved, they are the first speaker (Summer) and the second speaker (Tom). The above example has the function to offer something to do with the first speaker (Summer). It can be seen that the second speaker asks it after the first speaker (Summer) says "Please. I don't know anything about architecture." So it makes the second speaker offer to draw her something. The response of it is "Yeah." means she agrees with it.

\section{Conclusions}

There are five forms of yes-no questions found in the data source the movie"500 Days of Summer", belonging to the major classes of the question. The yes-no question found in the data were (positive yes-no question, negative yesno question, the yes-no question with modal auxiliary, tag question and declarative question). According to the theory mentioned one above, six functions of the sentencea in the data were found; they are (a) Asking for request; (b) Confirming; (c) Offering; (d) Asking for information; (f) Asking for permission.

Mostly yes-no question found in the data is asking for information and confirmation. However, the least occurrences are suggestion and greeting.

\section{Bibliography}

Jackson, H. 2002. Grammar and Vocabulary: A Resource Book for Students. London: Paperback.

Quirk, Randolph and Greenbaum. 1985.

A Comprehensive Grammar of English Language. London: Longman Group Ltd.
Thomson A.J and A.V. Martinet. 1986. A Practical English Grammar. New York: Oxford University Press.

Huddlestone. 1991. English Grammar: An Outline. London: Cambridge University Press.

Axelson. 2006. Movies, Mind and Meaning - Studying Audience and Favourite Films.Sweden.Uppsala University and Dalarna University 791 88 Falun. 